\title{
GESTATION OF THE CLINIC
}

\author{
by \\ TOBY GELFAND*
}

Michel Foucault's Naissance de la clinique (Paris, Presses Universitaires de France, 1963) makes a brilliant case for the sudden emergence in the late eighteenth century of the hospital clinic as the central concept and institution of Western medicine. Foucault's thesis, briefly stated, sees the birth of the clinic as an "essential mutation in medical knowledge" arising out of a general epistemological transformation and the Revolutionary re-structuring of French society. ${ }^{1}$ There is for Foucault no link between the new medical discourse and the way physicians of the earlier eighteenth century perceived and described disease. A system of medical knowledge based on abstract naming and typing of diseases disappears utterly before one which achieves knowledge by sensory observation, and detailed, graphic reporting and analysis of what has been seen in sick persons.

Foucault is well aware that clinical medicine in the literal sense of bedside study of patients and compilation of case histories is at least as old as Hippocrates. In a chapter on 'The Old Age of the Clinic', he notes that hospital clinics modelled after Boerhaave's famous Leyden institution, existed throughout eighteenth-century Europe, though they were peculiarly rare in France. However, these clinics or "protoclinics", Foucault insists (and I think rightly), differed radically from their modern counterpart, and therefore the former did not and indeed could not evolve into the latter. $^{2}$

The Boerhaavian clinic consisted of human specimens exemplifying categories of the accepted medical taxonomy. It selected these patients from a much larger hospital population in order to provide students with a representative sample of the types of diseases. The sole function of the clinic thus was didactic - the transmission of already accepted knowledge from professor to students. In a manner similar to the traditional public anatomy lesson, the eighteenth-century teaching clinic was, in large measure, a

\footnotetext{
* Toby Gelfand, Ph.D., Associate Professor, Hannah Chair of the History of Medicine, University of Ottawa, Ottawa, Canada KIN 9A9.

An earlier version of this paper read to the XXVth International Congress of the History of Medicine (Quebec, August 1976) appears in the Proceedings of that congress. Some sections are also in my Professionalizing modern medicine: Paris surgeons and medical science and institutions in the eighteenth century (Westport, Conn., Greenwood Press, 1980).
}

' Naissance de la clinique, 2nd ed., Paris, Presses Universitaires de France, 1972, p. xiv and passim.

${ }^{2}$ Ibid., pp. 53-62. 


\section{Toby Gelfand}

ceremonial demonstration of a previously defined corpus of medical knowledge (une sorte de théâtre nosologique). ${ }^{3}$ The clinic, like the anatomy lesson, sought primarily to display or, at most, to confirm the truth of existing knowledge.

Unlike its successor, the proto-clinic was not a site for investigation, theory-testing, discovery, or research. The eighteenth-century clinic formed but a marginal structure in medical education just as it was marginal to the aims and concerns of hospitals of the Enlightenment. The new clinic, on the other hand, was to be central to the medical enterprise. Virtually co-extensive with medical inquiry, it took the total hospital (not merely selected cases at selected times) as its domain for research and teaching, blending together the two functions. ${ }^{4}$

At the end of the eighteenth century, this new and, in many respects, modern clinic emerged. Its birth, to pursue Foucault's metaphor, was altogether remarkable. A spontaneous and sudden event, it required neither parents, nor prior conception, nor any discernible gestation period. At most, one may attribute midwife-like functions to the thought and events of the Revolutionary period.

It seems to me that one may accept Foucault's thesis of the essential novelty of the medical clinic without invoking an unbridgeable discontinuity in the history of medicine. The present paper seeks to sketch a background for the clinic's nativity, a "gestation period", which may add to our understanding of its lineage while preserving the notion of a sudden emergence.

Two assumptions are made: the first, already mentioned, is that even the most radical innovations are seldom wholly without prior models which operate at the time to facilitate and rationalize historical change. Second, it is assumed, though it could be and will in part be shown, that eighteenth-century surgery and medicine constituted separate professions. ${ }^{5}$ The gestation of the clinic, it will be argued, took place not within academic medicine proper (here I accept Foucault's case against viewing the Boerhaavian-style teaching clinic as a precursor) but in the eighteenth-century surgical profession. For purposes of forcefulness and brevity, evidence will be presented only for surgeons in the hospitals of Paris, particularly the Hotel-Dieu of Paris, but the claim is capable of generalization to other large provincial hospitals in eighteenthcentury France and perhaps elsewhere in Europe. ${ }^{6}$

\section{II}

The first point to be noted is the intimacy of the connexion between surgeons,

\footnotetext{
${ }^{3}$ Ibid., p. 59. See William S. Heckscher, Rembrandt's Anatomy of Dr. Nicholaas Tulp, New York University Press, 1958.

4 Naissance de la clinique, pp. 62-64, 107-123. Foucault perhaps insists too strongly on the non-selectivity of the new clinic. Patients were still chosen for clinical lessons.

"In a strict doctrinal sense, surgery or "external medicine" and physic or internal medicine obviously both belonged to the "healing art". But, in terms of social and institutional realities of the eighteenth century, medicine and surgery remained separate professions. These distinctions began to fade, especially after mid-century, when the convergence of physicians and surgeons led to fruitful exchanges between the two fields. See Toby Gelfand, 'John Morgan and the origin of a modern concept of medical specialization', Bull. Hist. Med., 1976, 50: 511-535.

'T. Gelfand, Professionalizing modern medicine: Paris surgeons and medical science and institutions in the eighteenth century, Westport, Conn., Greenwood Press, 1980, p. 228, n. 19.
} 


\section{Gestation of the clinic}

whether considered as individuals or collectively as communautes, ${ }^{*}$ and urban hospitals. Young surgeons trained and worked in these charitable institutions for the sick poor. The various names by which they were known - apprenti, compagnon, pensionnaire, and, most often, simply garçon - were common guild designations and reflected the fact that hospital service evolved naturally from the surgical guild's apprenticeship requirements. The statutes of the Paris College of Surgery in fact recognized service in one of the major hospitals of the city as superior to the ordinary apprenticeship under a private practitioner. ${ }^{\text {? }}$

By the eighteenth century, surgeons could look back upon a long tradition of service at the Hôtel-Dieu of Paris. Since at least the sixteenth century, young barber-surgeons worked in the ancient hospital for periods of several years. The best-known was Ambroise Paré who served three years at the Hôtel-Dieu in the 1530s. The hospital employed two garçons surgeons in 1561 and then four in $1584 .^{8}$ During the late seventeenth and early eighteenth centuries, the numbers of young surgeons at the Hôtel-Dieu rose substantially. In 1680 the Hôtel-Dieu had forty-five posts for externes (young surgeons who worked at the hospital during the day but did not live there); by 1703 there were sixty externes, and in 1726, the number of such positions was fixed at a maximum of seventy-four, though many more young men sought admission. That same year the administrators of the Hôtel-Dieu set the total of house surgeons at 100 , a figure which remained nearly constant until the Revolution. ${ }^{9}$ From the 1720 s, therefore, and extending over more than sixty years, the Hôtel-Dieu had a stable, wellorganized surgical house staff. Talented young surgeons could remain long beyond the three years which Paré had served. Tenures of a decade or even longer were not uncommon for resident surgeons. ${ }^{10}$

A closer look at the organization of surgeons in the Hôtel-Dieu reveals an elaborate hierarchy. Above the externes were twelve commissionaires, who received meals in the hospital, and above them twelve compagnons or internes, who had both room and board. At the apex of this sharply sloping pyramid of 100 surgeons were two men: a chief resident student, the so-called gagnant-maitrise, who in exchange for six years' hospital service "gained his mastership" in the Paris College of Surgery, without sustaining the usual examinations and expenses, and the chief surgeon, who alone of all the hospital surgeons already was a master of the College.

To be admitted as an externe, the young surgeon had to meet age (eighteen years) and religion (Roman Catholic) requirements, pass a perfunctory examination, and, most important of all, present a letter of recommendation from a patron. Advance-

\footnotetext{
* The "community" or guild of surgeons became known as a "College" in Paris around 1750.

'Lettres patentes du roi en forme d'Edit, portant règlement pour le Collège de Chirurgie de Paris, Paris, 1768, art. 82. Two years' service in a Paris hospital or three years in a military hospital (les hôpitaux des villes frontieres) were considered equivalent to three years of private apprenticeship in meeting requirements for the mastership in surgery.

'Marcel Fosseyeux, L'Hôtel-Dieu de Paris au XVIF et au XVIII' siécle, Paris, 1912, p. 401.

'Léon Brièle (editor), 'Délibérations de l'ancien bureau de l'Hôtel-Dieu', in Michel Moering, M. G. Quentin, and Léon Brièle (editors), Collection de documents pour servir à l'histoire des hôpitaux de Paris, 4 vols., Paris, Imprimerie Nationale, 1881-1887, vol. 1 (1881-1883), pp. 217, 245, 293-294.

${ }^{10}$ See note 26 below.
} 


\section{Toby Gelfand}

ment within the hierarchy depended on seniority of service and on practical and oral examinations which became more demanding at successive levels and as reforms were made during the century. By the last decade of the Old Regime, senior compagnons engaged in a genuine competitive examination or concours for vacant posts of gagnant-maitrise. ${ }^{11}$

The concours thus served as a mechanism for entry into and ascension up the ranks of the surgical hierarchy. The example of an éleve en chirurgie named Barbier, who applied for admission to the Hôpital-Général in 1780, illustrates the increasing rigour of the process as well as one young surgeon's motives for seeking a hospital post. Claiming that a relative had given money to the Hôpital-Général at the end of the seventeenth century, Barbier believed his request "to continue his studies ... in a house which had places for several young surgeons" deserved to be honoured. The hospital Board turned him down, but was willing to grant priority to compete in the next concours, a prospect Barbier apparently found unsatisfactory. In this instance patronage did not offset a test of competence. ${ }^{12}$

The hierarchical organization of surgeons at the Hôtel-Dieu lent itself readily to teaching. Hospital administrators encouraged senior surgeons to instruct those less experienced, and they supported formal lessons. To this end, regular courses of anatomical demonstrations and dissections were set up during the first decade of the eighteenth century at the Hôtel-Dieu and, shortly afterwards, at the other major hospitals. In 1725 the administrative Board of the Hôtel-Dieu reminded chief surgeon, Boudou, that his duties included gratis instruction of house surgeons in "the principles and practice of surgery". The administrators, however, never disguised the fact that the first and foremost task of their surgical "workers" was to carry out orders for the treatment of patients. ${ }^{13}$

The twenty-four compagnons and commissionaires were the work-horses. The compagnons, in particular, as residents, could be called upon at any time. Division of labour occurred in the rotation of such duties as the admission of new patients, emergency treatment at night, and service in the obstetric wards or in the lithotomy room. A compagnon's function also depended upon his seniority at the Hôtel-Dieu; the older surgeons assisted in major operations, like cutting for the stone, while the less experienced performed simpler chores, including barber's work. ${ }^{14}$ The main job of all compagnons, however, was the daily round of minor surgery, wound dressings, and phlebotomies for hundreds of indigent sick. An "order and duty" adopted in the mid-seventeenth century indicates that rounds began at $5.30 \mathrm{a} . \mathrm{m}$. and took place twice daily for $\mathbf{4 0 0}$ surgical patients; at the end of the Old Regime, chief surgeon

i1 See Gelfand, op. cit., note 6 above, pp. 110-113.

${ }^{12}$ Archives nationales, F 15245 . There were approximately fifteen surgical residents at Bicêtre and the Salpêtrière, including two gagnants-maîtrise.

${ }^{13}$ Archives de l'Assistance Publique, liasse 1438, 'Délibérations de l'ancien bureau de l'Hôtel-Dieu' (8 août 1725). For lessons in Paris hospitals, see T. Gelfand, 'The "Paris Manner" of disssection: student anatomical dissection in early eighteenth-century Paris', Bull. Hist. Med., 1972, 46: 112-114. Délibérations, I, $194-257$.

14 Délibérations, I, 224. 


\section{Gestation of the clinic}

Desault led his compagnons through a comparable routine three times per day. ${ }^{15}$

During two years of initiation to hospital service, externes were expected merely to accompany the compagnons, serving as assistants; they were not to "touch or dress the wounds of any patient" without explicit orders from the chief surgeon. In practice, however, externes filled in for overburdened or merely lazy compagnons who wished to delegate work to someone lower in the hierarchy. ${ }^{16}$

At the opposite extreme from the externes, the gagnant-maitrise undertook major operations either on his own or together with the chief surgeon. A veteran of many years on the wards, the chief resident surgeon of the Hôtel-Dieu occupied a unique hybrid position. On the one side were his fellow-apprentices who, like himself, worked without pay in exchange for training in their craft. On the other, was his future colleague in the Paris College, the chief surgeon, with whom the gagnant-maitrise shared ultimate responsibility for the functioning of surgical services and the supervision, examination, and instruction of the 100 subordinate surgeons. A former gagnant-maitrise, Cosme Dangerville, sketched his hospital career as follows: admission to the Hôtel-Dieu as externe in 1752; a fairly rapid rise through the surgical hierarchy to become gagnant-maittrise in 1764; as gagnant-maittrise, the performance of major operations - lithotomy, trepanation, amputation - supervision of the obstetric wards, and presentation of clinical and post-mortem studies to the Academy of Surgery; finally, reception into the Paris College of Surgery in 1770, after a total of eighteen years in the Hôtel-Dieu. ${ }^{17}$

Hospital administrators testified on numerous occasions to the indispensability of surgeons to their institution. Even the lowly externes were said to be "absolutely necessary" ${ }^{18}$ The administrators subjected externes to the same rigorous discipline as the resident surgeons. All had to obtain special permission to be excused from their work; violation of the rules might lead to dismissal, as happened to one externe who was repeatedly absent in 1729.19 Different aspects of the same paternalism were the police protection administrators provided surgical workers on their way to the HôtelDieu in the early morning hours and the care they received when ill. ${ }^{20}$

The above relationship stood in marked contrast to that between the Hôtel-Dieu and the medical profession. Medical students attended the hospital or not as they pleased. The Paris Faculty of Medicine offered little incentive for students to do so; its statutes did not envisage hospital service as part of medical education. Those students who visited the wards came, in effect, as spectators who had no formal obligation to the hospital nor responsibilities to the sick poor. Thus when young doctor Helvétius bravely attended morning rounds during the frigid winter of 1709 , his alarmed family urged him to desist. ${ }^{21}$ Similar options and solicitude did not apply to busy and equally

\footnotetext{
1s Ibid., 106, 155; See T. Gelfand, 'A confrontation over clinical instruction at the Hôtel-Dieu of Paris during the French Revolution', J. Hist. Med., 1973, 28: 279.

16 Délibérations, I, 106, 185.

${ }^{17}$ Bibliothèque Nationale, Coll. Joly de Fleury, 1214, fols. 179-180.

18 Délibérations, I, 318.

19 Ibid., 303.

${ }^{20}$ Ibid., 263, 318.

21 'Eloge de M. Helvétius', Histoire de l'Académie Royale des Sciences, 1755, Paris, 1756, p. 162.
} 


\section{Toby Gelfand}

cold surgical externes.

Hospital administrators evidently regarded the presence of medical students as superfluous and possibly harmful. The house surgeons shared this point of view and warmly reinforced it whenever the opportunity arose. In 1730 Pierre Boudou, the chief surgeon, accused rowdy medical students of provoking disturbances at the HôtelDieu. Citing a recent fracas during an operation on the wards, Boudou argued that the care of patients by surgeons must take precedence over the instruction of medical students. The administrators strongly supported their chief surgeon:

... disorders are caused by medical students who have taken to accompanying physicians of the HogtelDieu during rounds ... they have forced the surgeons of the house to yield their place, despite the fact that their [the surgeons'] presence is indispensable for the execution of physicians' orders. ${ }^{22}$

In response to the problem dramatized by the 1730 incident, the administrators of the Hôtel-Dieu adopted a regulation which limited the numbers of medical students and the hours during which they could attend, and denied them access to many parts of the hospital. This regulation and a similar one for the Charité hospital remained in effect until the Revolution. ${ }^{23}$

While surgeons appeared on official lists of persons residing in hospitals, together with apothecaries, various artisans, religious personnel, secular administrators, and the patients themselves, physicians were not included on such registers. The consultant physicians of the Hôtel-Dieu, who numbered eight during most of the century, honoured their obligations to the sick poor more in the breach than the observance. Although regulations called for physicians to make rounds daily, some doctors went for several months at a time without, as the administrators complained, "setting foot in the Hôtel-Dieu". ${ }^{24}$ Responsibility for routine medical supervision and services fell to the house surgeons. Emoluments reflected this unequal contribution of surgeons and physicians. The chief surgeon, who usually lived in the hospital even though not required to do so, received $£ 2,000$ per annum. Consultant physicians, despite their indisputably higher social status, got somewhat less than half that sum. ${ }^{23}$

Why were there such discrepancies between the medical and surgical professions vis $a$ vis hospitals? This is a complex question which can here be only briefly considered. First, hospital posts offered advantages to surgeons which interested physicians to a much lesser degree if at all. Among the most prosaic were experience with routine hospital chores involving bloodletting, wound dressing, and other "surgical" skills. The hospital provided abundant opportunities to learn normal and pathological anatomy and to practise surgical operations on the cadavers of deceased indigent patients. Pathological anatomy had direct relevance for surgeons as compared to marginal utility for eighteenth-century physicians. Thus, the role of hospitals in the

\footnotetext{
22 Délibérations, I, 306.

23 Ibid., 307; Ordonnance de Police, portant règlement sur ce qui doit observer par les étudiants en médecine et garçons chirurgiens lors de la visite des malades dans l'hôpital des frères de la Charitè. I6 mai 1730, Paris, 1730. (Copy in Archives Nationales, AD XI, 21.)

24 Délibérations, I, 340.

${ }^{25}$ Ibid., 250; A. Corlieu, 'Les chirurgiens de l'Hôtel-Dieu du XV' au XIX' siècles', Gaz. Hôp., 1901, 74: $109,129$.
} 


\section{Gestation of the clinic}

acquisition of knowledge of anatomy and surgery was clear, while their place in medical epistemology remained vague. Increasingly during the eighteenth century, persons of all social classes came to accept the hospital as an appropriate setting for surgical operations, though the latter remained a terrible ordeal. For most medical conditions, hospitals were perceived as places to be avoided.

Apart from its intrinsic value, a hospital position brought palpable economic and social benefits to young surgeons who commonly came from the provinces to Paris nearly penniless: the security of regular work, of food and lodging if one were fortunate to rise beyond externe, the acquisition of marketable skills, and the prestige of a certificate testifying to hospital experience. For those few surgeons who attained the upper ranks of the Hôtel-Dieu hierarchy, a successful career in Paris was virtually assured. For the others, prospects improved for surgical careers in the army or on returning home. Hospital jobs thus offered a means of survival in the urban environment and the possibility of geographic and perhaps social mobility. These represented substantial, if not unique, incentives for the vast mass of the French common people, from whose ranks surgeons generally came. For physicians, who tended to come from more comfortable bourgeois families, a hospital job did not have similar allure.

\section{III}

It remains to be seen how the relationship between the surgical profession and hospitals, which we have sketched in the case of the Hôtel-Dieu of Paris, can be considered a locus for the gestation of the clinic. The major themes have already been stated. First, surgeons established a genuine presence in the hospital, and second, they took on responsibility for the ongoing treatment of patients. At the Hôtel-Dieu, tenure of surgical service varied from a minimum of two years for the externes to remarkable durations, sometimes as long as twenty years, for gagnants-maittrise. ${ }^{26}$ At the other major Paris hospitals (Charité, Bicêtre, Salpêtrière, Invalides) and their counterparts in the provinces (e.g. Lyons, Montpellier) gagnants-maitrise also held six-year appointments and directed subordinate resident surgeons. ${ }^{27}$

Clinical responsibilities helped define the hospital surgical hierarchy and provided the matrix for learning through practical experience. Several examples reveal this often-neglected aspect of the eighteenth-century hospital. At the massive HôpitalGénéral of Paris, the administration adopted a plan in 1750 for resident surgeons to divide their four years of service between the two major branch hospitals - the Salpêtrière and Bicêtre - each of which provided different clinical experiences. ${ }^{28}$ The Charité of Paris, renowned during the first half of the eighteenth century for its école pratique of anatomy, also had a reputation as a hospital where one could learn from

\footnotetext{
26 One gagnants-maitrise died in 1741 before completing his term of service but not before he had worked at the Hôtel-Dieu for more than twenty years. Another more fortunate surgeon completed a total of twentytwo years in the hospital in 1757. See Délibérations, I, 375-376.

${ }^{27}$ Statuts et règlements de l'Hôpital Général de la Charité et A umône Générale de Lyon, Lyons, 1765, pp. 140-142; Louis Dulieu, La chirurgie à Montpellier de ses origines au début du XIX'e siecle, Avignon, Les Presses Universelles, 1975, pp. 151-162. Other large provincial hospitals, such as Bordeaux, Toulouse, Nantes, etc., also had posts of gagnant-maitrise.

2oll. Joly de Fleury, 1230. fols. 42-43.
} 


\section{Toby Gelfand}

living patients. A contemporary description of the duties of house surgeons under Pierre Foubert, chief surgeon of the Charite during the early 1740s, indicates that responsibility went beyond the simple execution of orders:

The students whose number he [Foubert] had fixed at ten for the ordinary service of the patients were divided so that the one who cared for the patient in bed \#1 was responsible for \#\#21, 31, 41, etc. By this means, commands and obedience could not be misunderstood. Each student was required to keep an exact journal of the disease and of the course of treatment of those who had been confided to him. At the end of the cure, in cases of cure, and, after the autopsy in cases of deaths, he wrote up his findings in the form of a reasoned observation. ${ }^{29}$

Thus, in addition to administering treatment, young hospital surgeons kept written records of the clinical course and post-mortem findings in patients to whom they had been assigned. Their job, by its very nature, demanded first-hand clinical information, attainable only by questioning and examining patients at the bedside. Even at the busy and often chaotic Hôtel-Dieu, where formal clinical lessons did not begin until Desault's tenure in the late 1780s, compagnon surgeons evidently learned a good deal as they carried out their clinical responsibilities. Several compagnons went so far as to publish instructive case histories in the Journal de Médecine. In 1778, for example, Chandron, an interne of the Hôtel-Dieu, published an account of his management over a two-month period of a patient who had been admitted with a severe head wound, treated initially by the chief surgeon, and then "confined to my care" ${ }^{30} \mathrm{~A}$ decade or so later, these sorts of brief clinical accounts of hospital patients written by young surgeons filled Desault's Journal de Chirurgie. In the rise of this type of medical literature, the process of gestation and birth of the clinic is fairly clear.

The notion of an informal surgical clinic in eighteenth-century hospitals has several obvious limitations; if it did not we should be dealing with an actual birth, not a gestation. Virtually absent is the thrust toward research in the nineteenth-century sense of discovering fundamentally new medical knowledge. Second, as institutions, hospitals of the Old Regime, despite a makeshift alliance with surgeons, remained autonomous structures, administratively separate from the surgical as well as medical profession. Hospitals employed medical professionals rather than vice versa.

To the best of my knowledge, only in a single instance did an eighteenth-century hospital show a firm commitment to research and include medical men as administrators who were willing and able to implement this policy. The hospice of the Paris College of Surgery, founded by royal edict in 1774, met both criteria. ${ }^{31}$ But the exception tended to prove the rule. The small size of the hospice (twenty-two beds) and its modest financial resources precluded any extensive research or teaching programme. The hospice should be viewed as the late Enlightenment's tentative and inconclusive experiment with new roles for hospitals.

Clinical research as practised in the hospice of the College of Surgery and elsewhere

\footnotetext{
29 Antoine Louis, 'Eloge de Foubert' (1768), in E.-F. Dubois (editor), Eloges lus dans les séances de l'Acadèmie Royale de Chirurgie de 1750 à 1792, Paris, Baillière, 1859, pp. 124-125.

30 'Observations sur les plaies de tête où; l'os était à découvert', J. Méd., 1775, 44: 363-367.

${ }^{31}$ See T. Gelfand, 'The Hospice of the Paris College of Surgery (1774-1793). A unique and invaluable institution', Bull. Hist. Med., 1973, 47: 375-393.
} 


\section{Gestation of the clinic}

by eighteenth-century surgeons had a very narrow scope. It sought solutions to practical problems, problems which, for the most part, related directly to therapy; e.g., determining the best methods for performing operations for aneurysms or for bladder stones, testing new substances for dressing wounds or new instruments for catheterization of the urethra and treatment of strictures, etc. ${ }^{32}$ Rarely did this kind of research touch on fundamental theoretical problems such as the mechanism of wound healing or bone regeneration. In other words, the surgical clinic's limitations were those of surgery itself, an empirical, specialized discipline dealing with certain localized injuries and diseases in individual patients. Above all, surgeons concerned themselves with therapeutic techniques; i.e. the application of knowledge, not its production.

Nevertheless, within the limits of this context, one may perceive the formation of a clinic by surgeons in eighteenth-century hospitals, epitomized by the Hôtel-Dieu of Paris. Here, young surgeons worked and lived in an environment which conferred, along with responsibilities, opportunities for increasing mastery of anatomical and clinical knowledge. To a degree without precedent in earlier centuries or in medicine of the time, hospital surgeons experienced a spontaneous and total exposure to whatever they could learn from their patients. This involved, if not full-blown research, something quite different from the purely didactic Boerhaavean medical clinic with its carefully selected examples, formal presentations, and predictable lessons.

The medical Revolutionaries, though they liked to point to precedents at Vienna or Edinburgh or even in ancient Greece, seemed to realize that the new clinic in fact drew upon a surgical model. In 1790 the most influential plan for restructuring French medicine stated:

It would be easy to admit candidates into the hospitals as resident students [élèves internes] and to provide them with room and board. ... At the same time they would have excellent facilities for instruction. In the practical sciences, one learns well only what one does. Now the students admitted into hospitals would participate in the treatment of patients; they would tend them and live in their midst. This resource, already available to surgery ought to be shared by all parts of medicine . . . ${ }^{33}$ [my italics].

The Nouveau plan de constitution pour la médecine en France, prepared by the Société Royale de Médecine and presented by its secretary, Vicq d'Azyr, to the Revolutionary assembly, thus made an explicit connexion between surgery and hospital learning. At the Hôtel-Dieu of Paris, the Nouveau plan stated, "the most beautiful establishment [for clinical teaching] exists for surgery. And similarly, at Rouen". ${ }^{34}$

The Nouveau plan presented a consensus of opinion among French physicians

\footnotetext{
${ }^{32}$ See ibid., pp. 381-384, 391-393.

${ }^{33}$ Nouveau Plan de Constitution pour la Médecine en France, in Histoire de la Société Royale de Médecine, 1787 et 1788 , Paris, 1790, p. 63.

34 Ibid., p. 64. The Nouveau Plan observed in this context that hospitals would train instructors as well as students and thus "ouvrir une carrière qui n'a jamais eu lieu". In England where "on y trouve dans chaque hôpital une salle d'enseignement et des salles d'opérations et de dissection", hospitals approached this clinical goal. (". . . cet usage est à-peu-près suivi en Angleterre”) ibid., pp. 63-64. See also, Othmar Keel, La généalogie de l'histopathologie. Une révision déchirante, Paris, Vrin, 1979, pp. 51-57, 102-115.
} 


\section{Toby Gelfand}

that the hospital should become the central institution of the new medicine. A second guiding and widely accepted principle was that medicine and surgery should be united as one profession. Both principles were implemented with the creation of the écoles de santé in December 1794. Among many legacies from surgery, conceptual as well as institutional, which prompted Georges Cuvier to describe the Paris medical faculty in 1817 as "the old College of Surgery reinforced by a few physicians" were an emphasis on post-mortem dissection and the direct incorporation into the new school of the College of Surgery's hospice for rare diseases. The medical Faculty also took over the magnificent buildings of the old surgical college. Leaders of the Paris clinical school, including Pinel, Bichat, Richerand, and Laennec saw the incorporation of surgery into medicine as a major source of the vitality of their profession. ${ }^{35}$

Was the post-revolutionary hospital clinic then merely an adaptation and generalization of the eighteenth-century surgical clinic? We have already noted the limitations of the surgical clinic in this regard. Moreover, a smooth evolutionary interpretation would grossly simplify the complex structural transformation that involved interaction between medicine, surgery, and hospitals at the time of the Revolution. To claim too large an influence of the surgical precedent would distort the nature of the change as much as did some medical reformers of the period who tended to deny any direct relevance of the surgical example for medicine. ${ }^{36}$

The new clinic aspired to and, in considerable measure, achieved a profound change in the medical profession's control over hospitals. As the Société Royale de Médecine plan put it with regard to the network of provincial hospitals throughout France: "hospitals are not lacking for teaching, it is teaching which is lacking in hospitals". ${ }^{37}$ The reformers aimed to transform at least the major hospitals into machines for medical instruction by elaborate organization toward this objective. Medical men were to be directly involved in the administration of hospitals and to have extensive discretionary powers over the use of patients, cadavers, rooms, and other facilities for instruction. The chief physicians and surgeons at hospitals would always be clinical professors at the medical school, and all students would be required to follow a series of hospital courses. It was confidently assumed that "the welfare of patients is so compatible with instruction that it is impossible to do anything advantageous for one without benefiting the other". ${ }^{38}$ When compared with the loose and somewhat subservient arrangement the surgical profession had struck with eighteenth-century hospitals, the medical clinic is seen to be new.

${ }^{35}$ G. L. C. F. D. Cuvier, 'Eloge historique de Tenon', 1817, Recueil des éloges historiques lus dans les séances publiques de l'Institut de France, new ed., Paris, 1861, vol. 2, p. 91 . For a full discussion of the surgical background of French medical reform, see Gelfand, op. cit., note 6 above, pp. 131-188.

${ }^{36}$ One such was the physician Nicolas Chambon de Montaux (1748-1826). See T. Gelfand, "A clinical ideal: Paris 1789', Bull. Hist. Med., 1977, 51: 397-411, esp. 404-406. For the silence of many physicians with regard to surgical precedents, see Gelfand, op. cit., note 6 above, pp. 176-177. The passage quoted on p. 177 above was an unusually frank recognition of the surgical precedent.

${ }^{37}$ Nouveau Plan, op. cit., note 33 above, pp. 65-66.

${ }^{38}$ Ibid., p. 80. See ibid., pp. 61-67, 75-103 for general discussion of the proposed reform of hospital organization. On its implementation during the French Revolution, see Foucault, op. cit., note 1 above, pp. 37-52, 63-86, and Léon MacAuliffe, La Révolution et les hôpitaux, thèse de Médecine, Paris, 1901. 


\section{Gestation of the clinic}

\section{IV}

This paper has sought to introduce a nuance into Foucault's account of the "birth of the clinic" by showing the surgical precedents available to French medicine at the time of and indeed well before the Revolution. By neglecting this tradition, which admittedly remained tangential to the intellectual and social concerns of French physicians until around the middle of the eighteenth century, Foucault dramatized his assumption of a rupture with the past. By limiting himself to the discourse of an élite within but scarcely coextensive with the medical profession, Foucault largely missed the experience of another organized medical group, secondary in status but in fact much more numerous, widely distributed and conspicuous in hospitals than physicians.

Foucault's book, together with the subsequent extensive exploration of the archives of Sociéte Royale de Médecine, spearheaded by the Annales school, ${ }^{39}$ leave little doubt about the fundamental transformation of medicine at the end of the eighteenth century. Yet much of this copious and rich harvest in recent medical historiography has also minimized the role which surgery played as a model for medical change, a notion persuasively sketched out by Temkin more than a decade before Foucault's original study..$^{40}$ Elsewhere I have developed the position that French medicine after mid-century, and particularly after the founding of the Sociéte Royale in 1776, successfully assimilated progressive aspects of French surgery into a new clinical ideal for medicine. ${ }^{41}$ In the process, the origins of some elements of clinical medicine were obscured; indeed it was in the interest of contemporary physicians to stress the novelty of their endeavour. At the same time, the clinic, as it emerged during the Revolution and further coalesced at the turn of the century around Bichat's conceptual innovations in general anatomy, physiology, and pathology constituted a new structure. Foucault's expression "birth" appears justified.

It seems legitimate, none the less, for the historian to locate the separate strands out of which this new clinic emerged. For we are not discussing only a question of priority or a philosophy of historical change (discontinuity versus evolution) or the privileging of certain kinds of sources (professional élites versus a lower professional stratum). We are seeking to understand the genesis and structure of a modern medical profession in post-revolutionary France. Why, for example, was the anatomical lesion the basis of physiological as well as pathological thought? Or more broadly, how did a new kind of technologically oriented scientific medicine (and physician-technician) supplant older more philosophically based medical structures? To begin to answer such questions, it seems important to be aware of the degree to which surgical precedents entered into the medical revolution at Paris.

\footnotetext{
${ }^{39}$ See, e.g., the collection of essays in J.-P. Desaive et al., Médecins, climat et épidemies à la fin au XVIII' siècle, Paris, Mouton, 1972, and esp. J.-P. Peter, 'Une enquête de la Société royale de Médecine (1774-1794). Malades et maladies à la fin du XVIII siècle', Annales Econ. Soc. Civ., 1967, 22: 711-751.

${ }^{40} \mathrm{O}$. Temkin, 'The role of surgery in the rise of modern medical thought', Bull. Hist. Med., 1951, 25: 248-259; Les Machines à guérir (Paris, Institut de l'Environnement, 1976), a collection of essays by Foucault and his students, continues to view medicalization in terms of a sudden re-orientation on the part of physicians. See esp. Anne Thalamy, 'La médicalisation de l'hôpital', ibid., pp. 43-53.

${ }^{41}$ Gelfand, op. cit., note 6 above, esp. pp. 155-160, 192; Gelfand, op. cit., note 36 above, pp. 397-411.
} 


\section{Toby Gelfand}

\section{SUMMARY}

A nuance is introduced into Michel Foucault's notion of the sudden "birth" of the clinic at the end of the eighteenth century. While not disputing the essential novelty of the process that saw the hospital assume a dominant place within the structure of Paris medicine (and vice versa) at the time of the Revolution, the present paper shows the intimate connexion between hospitals and the French surgical profession during the last century of the Old Regime. Epistemological and social factors contributed to the linkage between surgeons and hospitals, a relationship strikingly evident at the Hôtel-Dieu of Paris where an elaborate surgical student hierarchy developed. The presence, work, and responsibilities of young surgeons within this hospital are explored and contrasted with the relative absence of medical students. Despite limitations as a research instrument and in terms of the status accorded by hospital administrators, the eighteenth-century surgical clinic served later medical reformers as a useful precedent. Its historical role in the "gestation"of the clinic helps explain why the new medical structure displayed certain specific and general characteristics. 